\title{
SPACE LOGISTICS ON THE PLANETS OF THE SOLAR SYSTEM AND THE STAR FIELDSPACE LOGISTICS IS NOT A VISION ANYMORE BUT HAS BECOME REALITY ŰRLOGISZTIKA MÁR NEM VÍZIÓ HANEM VALÓSÁG
}

\author{
DR. ESTÓK SÁNDOR PHD ${ }^{1}$ \\ szakközgazdász \\ estok.sandor@gmail.com
}

\section{DOI 10.47273/AP.2020.21.66-82}

\begin{abstract}
"The Earth is the cradle of humanity, but mankind cannot stay in the cradle forever. Mankind will not forever remain on Earth, but in the pursuit of light and space will first timidly emerge from the bounds of the atmosphere, and then advance until he has conquered the whole of circumsolar space."
\end{abstract}

Konstantin Eduardovich Tsiolkovsky ${ }^{2}$

\begin{abstract}
In my article, after a short overview of space exploration of the past decades, I analyze the current situation and vision of research of the Solar System.

I present the possibilities of exploiting the Moon and Mars, along with the feasibility of living conditions, with logistics in the main focus.

I demonstrate the emergence of the private sector in the space program of the USA, as a new potential, the continuously intensifying space competition and the role of the participating countries.

I highlight the application of logistic and hybrid logistic solutions in the area, with the correlations of risk and security.

I also touch upon the legal background of lunar mining and the extraction of rare earths, ownership of the extracted and acquired materials and the possibilities of their commercial distribution, as well as the distant future of space logistics in space exploration.
\end{abstract}

Keywords: space logistics, space utilization, space exploration, space mining, lunar utilization

\footnotetext{
1 estok.sandor@gmail.com | ORCID ID: 0000-0002-2422-5293 | Óbuda University Doctoral School on Safety and Security Sciences

${ }^{2}$ Ciolkovszkij, K. E., 1960. Távol a Földtöl. Budapest: Móra.
} 


\begin{abstract}
ABSZTRAKT
Cikkemben az elmúlt évtizedek ürkutatásának rövid áttekintése után elemzem a Naprendszer kutatásának jelenlegi helyzetét és jövőképét.

Bemutatom a Hold és a Mars kiaknázásának lehetőségeit, az életkörülmények megvalósíthatóságával együtt, fő hangsúlyt fektetve a logisztikára.

Bemutatom a magánszektor megjelenését az USA ürprogramjában, mint új potenciált, a folyamatosan erősödő ürversenyt és a részt vevő országok szerepét.

Kiemelem a logisztikai és a hibrid logisztikai megoldások alkalmazását a területen, a kockázat és a biztonság összefüggéseivel.

Kitérek a holdbányászat és a ritkaföldfémek kitermelésének jogi hátterére, a kinyert és megszerzett anyagok tulajdonjogára és azok kereskedelmi terjesztésének lehetőségeire, valamint az ürkutatás távoli jövőjére is
\end{abstract}

\title{
1. Historical background
}

As early as in the $19^{\text {th }}$ century there were dreams about conquering Space. The founder of the theory of modern rocket science and space exploration was Konstantin Eduardovich Tsiolkovsky (1857-1935), whose famous saying is quoted to this day.

Tsiolkovsky, in his ample work, elaborated the kinetic theory of gases and recognized the principles to control dirigible airships. He prepared a flying structure with a metal frame on a pair of wings.

He was the first one to determine the notion of escape velocity $(8 \mathrm{~km} / \mathrm{s}){ }^{3}$

The beginning of the Space Age:

the launch of the first artificial satellite Sputnik 1 (4 October 1957), then of Sputnik 2 with Laika the dog aboard (4 November 1957).

It was a great sensation, when in 1961 Yuri Gagarin orbited Earth aboard Vostok 1 in 108 minutes. ${ }^{4}$ Then Valentina Vladimirovna Tereshkova orbited the Earth 48 times (16 June 1963) aboard Vostok-6 and returned successfully after 3 days. Alexei Arkhipovich Leonov, Soviet and Russian cosmonaut, Air Force major general, on 18 March 1965, became the first person to conduct a spacewalk, exiting the capsule during the Voskhod 2 mission. Leonov's second,

\footnotetext{
${ }^{3}$ Ciolkovszkij, K. E., 1960. Távol a Földtől. Budapest: Móra.

${ }^{4}$ Csató, I., 1963. A kozmosz partján (Az ürkutatás története). Budapest: Kossuth Kiadó.
} 
also historical trip into space was as commander of the Soviet half of the first international space program Soyuz-Apollo. ${ }^{5}$

Project Gemini was announced as third but in fact it was the second human spaceflight program of the United States. The main parts of the program (the flights) were conducted between April 121964 and November 15 1966. These flights divided the program into three main phases. In the first phase, during the first two unmanned test flights (Gemini 1 and 2) mainly the functionality of the spacecraft was tested, as well as during the first crewed flight (Gemini 3). The second phase consisted of carrying out the main objectives of the program with the record flights (Gemini IV, V, VI-A, VII, VIII), and in the last phase the last four flights up to Gemini XII were to enhance skills. ${ }^{6}$

Wernher von Braun is also worth mentioning. He is the theoretical father of rocketry, who developed the ideas of the Russian Tsiolkovsky and the public theoretical research of the American Robert Goddard, finding the most suitable solution to rocket flight in liquid propellant rocket engines.

His work was intended to conquer outer space, although in the beginning his possibilities were limited to developing missiles. ${ }^{7}$

Apollo 11 was the fifth crewed mission of the Apollo program and the first attempt to land on the Moon. It was the spaceflight that first landed humans on the Moon. The main objective of the program was the landing of Neil Armstrong and Buzz Aldrin on Mare Tranquillitatison (Sea of Tranquility), on a lunar lava-plain on the closer side of the Moon, on July 20, 1969. They spent about two and a quarter hours together outside the spacecraft, and they collected 47.5 pounds ( $21.5 \mathrm{~kg}$ ) of lunar dirt and rock samples to bring back to Earth. The third member of the expedition was Michael Collins who flew the Command Module alone in lunar orbit while they were on the Moon's surface with the Lunar Module.

The successful landing on the Moon was thought to be the greatest scientific achievement of mankind, remaining influential up to now. Besides, it was a symbolic event uniting Humanity

\footnotetext{
5 Portree, D. S. \& Trevino, R. C., 1997. Walking to Olympus: An EVA Chronology, NASA History, Washington DC: NASA Headquarters.

${ }^{6}$ Hacker, B. C. \& Grimwood, J. M., 1977. On the Shoulders of Titans: A History of Project Gemini (PDF). NASA SP-420, Washington, D.C: MASA.

${ }^{7}$ Wernher von Braun, 1966. History of rocketry \& space travel. hely nélk.:Crowell.
} 
during the Cold War, which led in a short time to the end of Space Race, and the easing of Cold War tensions. ${ }^{8}$

The future is the Space Station and the Moon will get into focus after 2020, when the Space Station is finished. The objective is to explore the Moon with probes and rovers, while the orbiting units are doing full reconnaissance around the Moon.

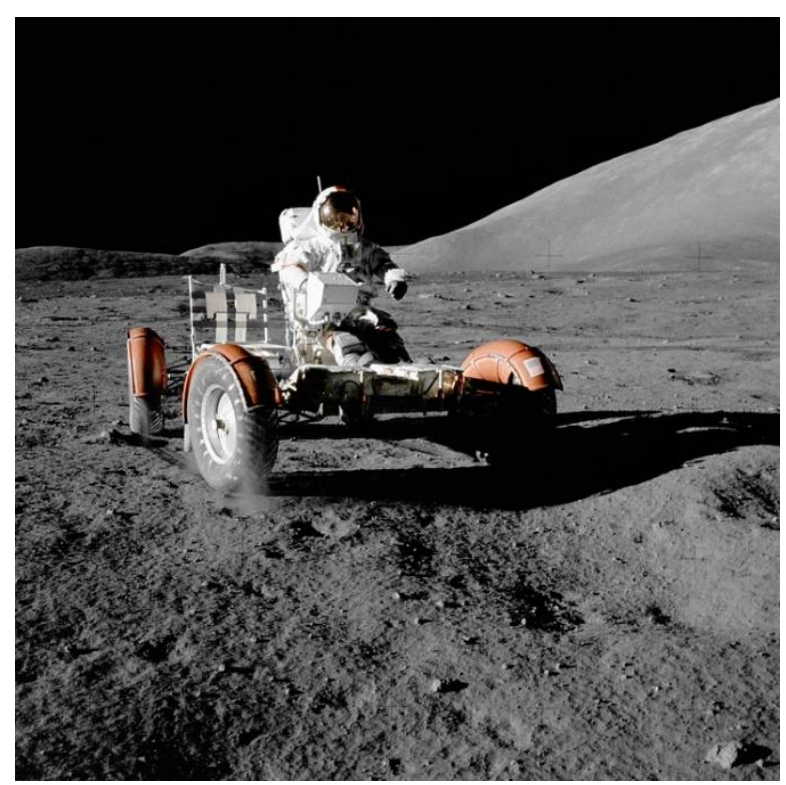

Moon vehicle ${ }^{9}$

In the $20^{\text {th }}$ century, the American and Russian research had continued in full force, for more than 50 years from the beginning.

The construction of a space base, the industrialization of the Moon, the extraction of important substances and the construction of a fusion power plant are prioritized.

Looking back on the analyses, researches, results of the past two decades of the $21^{\text {st }}$ century, it is justified, that thanks to the genial ideas of researchers and scientists, space objectives have become a reality.

"By the $21^{\text {st }}$ century the conquest of Space has slowed down distressingly. However, this is the beginning of a new chapter, which will hopefully give new impetuous to manned space travel. On May 27 2020, 22:32 Hungarian time the first private vehicle capable of crewed spaceflight will be launched: the capsule of Crew Dragon on top of a Falcon-9 space launcher, with two

\footnotetext{
${ }^{8}$ Mailer, N., 2010. F. Moonfire - Az Apollo-11 hösies utazása - Az Apollo-11 hösies utazása. ISBN:9783836522298 szerk. hely nélk.:Taschen.

${ }^{9}$ NASA, 2020. Lunar Rover Apollo 17. [Online]

Available at: http://images.jsc.nasa.gov/luceneweb/caption.jsp?photoId=AS17-146-22367

[Date of access: 28102020 ].
} 
American astronauts aboard. Although the direct objective is the International Space Station, the long-term perspective is the reduction of costs and the restart of space race."10

\section{The USA vision for the future}

Civil companies were also involved in space industry, in R\&D and application related to the exploration of the Solar System. The Mars mission raised questions and it was not specified why exactly it was cancelled. The construction of cargo spacecraft requires the elaboration and use of new technologies. The landing on Mars is planned for 2040. Landing on celestial bodies and carrying out successful missions beyond the Solar System require a successful Mars mission, but their planning would require extreme efforts.

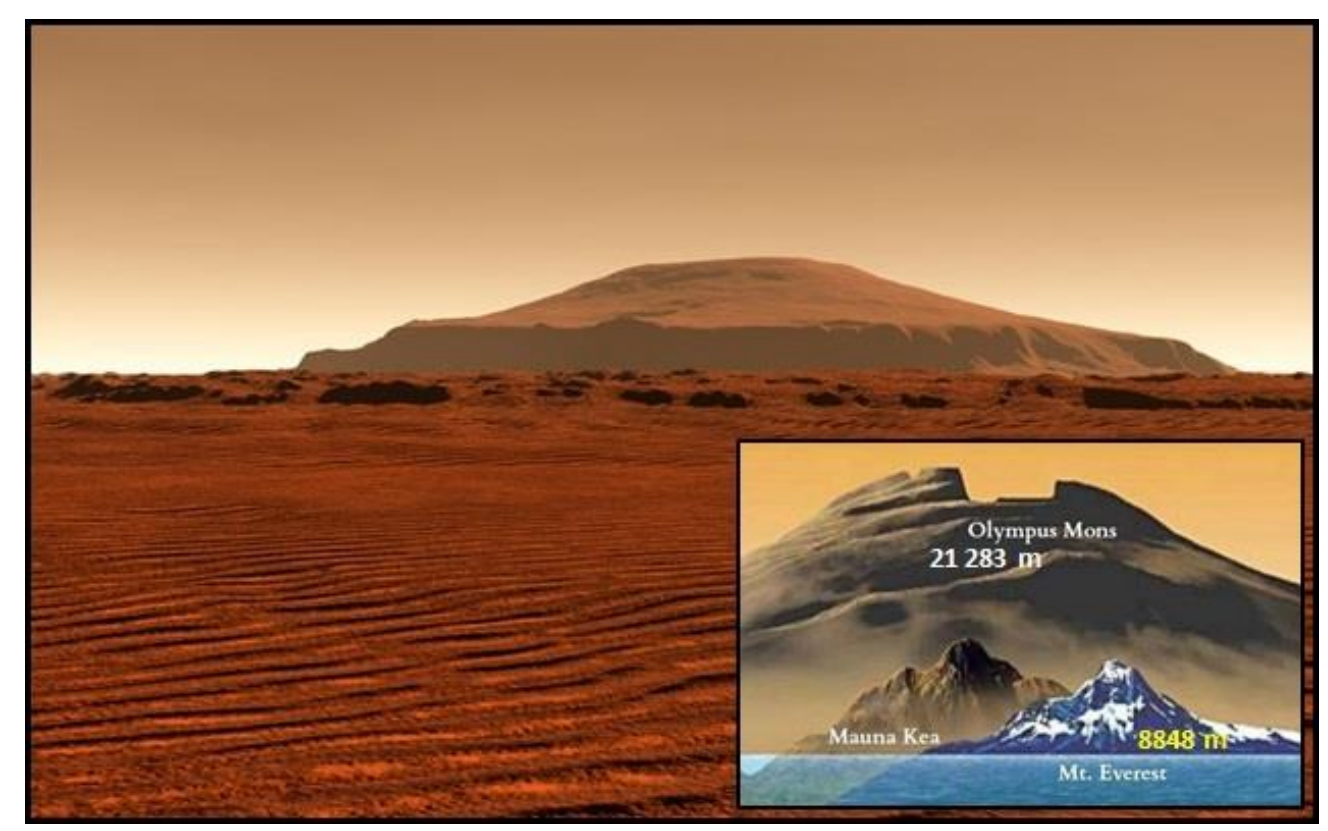

The highest mountain of the Solar System is located on Mars; it is the Olympus Mons, next to which Mount Everest seems to be a small hill. ${ }^{11}$

When we will be able to develop the technology to populate the Moon, we will be able to make Space habitable for humans in the long term - said Michelle Hanlon at the Air and Space Law Program at the Mississippi University of Law. ${ }^{12}$

\footnotetext{
${ }^{10}$ Csillagvizsgáló , b., 2020. Csillagvizsgáló Blog. [Online] Available at: https://csillagvizsgalo.blog.hu/2020/05/26/a_sas_leszallt_a_solyom_meg_fel_fog [Date of access: 02112020$].$

${ }^{11}$ Mizantroop, 2019. Mizantroop Blog. [Online] Available at: https://mizantroop.blog.hu/2019/07/21/holdra_szallas_ujra_vagy_marsra_szallas_eloszor [Date of access: 02112020 ].

${ }^{12}$ Kitekintő, 2019. Kitekintö.hu. [Online]

Available at: https://kitekinto.hu/2019/07/27/europan-kivul/otveneves-szabalyokkal-vagunk-neki-az-ur-
} 
According to the vision of Bezos, fuel can be produced of ice in the shadow craters of the Moon, with which the Blue Origin can land on the Moon in 2024.

NASA intends to set up a space station on the Moon, from where the astronauts could operate robotic probes to gather minerals that can be found there. China and India have Moon programs and further plans concerning the Moon. ${ }^{13}$

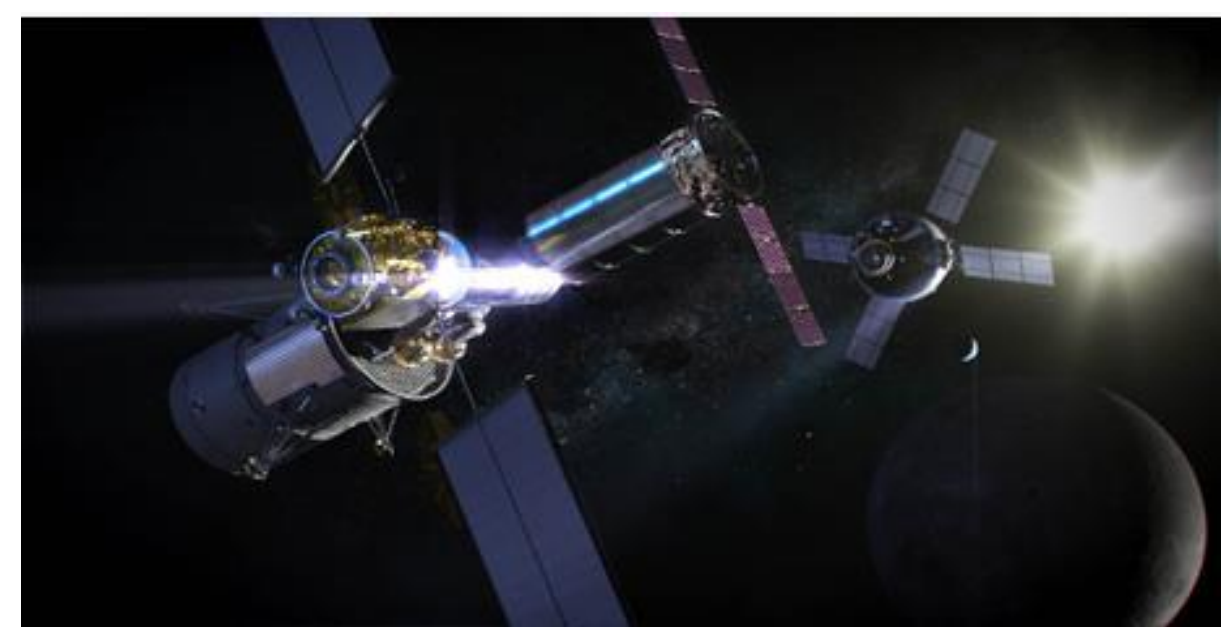

Gateway orbiting the Moon with a cargo spacecraft docked and the approaching manned Orion spaceship (Concept art by NASA) ${ }^{14}$

Development is slow and meanwhile the targets change: Moon, Mars and sometimes small planets, but one thing is certain, NASA cannot count on a financing proportional to the Apollo era. In the meantime, new objectives have been identified, such as the setting up of a permanent lunar base, which is very unlikely to be achieved, until the programs are financed on a yearly basis, even if under the Trump administration the return to the Moon was identified as the main goal.

After 2020 there will be no space shuttles, but there will be a space station. The objectives are the Moon mission and later the Mars mission, with vertical take-off and landing manned and

meghoditasanak/173806/

[Date of access: 0311 2020].

${ }^{13}$ Kitekintő, 2019. Kitekintö.hu. [Online]

Available at: https://kitekinto.hu/2019/07/27/europan-kivul/otveneves-szabalyokkal-vagunk-neki-az-urmeghoditasanak/173806/

[Date of access: 0311 2020].

14 Ürvilág, 2019. Ürvilág.hu. [Online]

Available at: http://www.urvilag.hu/a holdnal/20190819_a_gateway lakomodulja

[Date of access: 0411 2020]. 
cargo spacecrafts, and the construction of spaceships capable of traveling in interstellar space, to explore planets beyond the Solar System. ${ }^{15}$

After 2020, the Russian module of the International Space Station will be detached, and with its elements Russia will construct its own space station.

\section{The situation in Space from the logistic point of view}

The "Space March" of China is thorough and reliable, always implemented on schedule. In the future, the Moon mission will be highlighted; by 2030 the Chinese will land on the Moon. The good strategic goals and the plans to construct a space station after 2020 can be a big advantage. In the long term, the lunar base, the distribution stations, the power plants, the industrialization and exploitation of the Moon, the excavation of energy-minerals and the transformation of heat into electricity could mean security. Besides the Moon and Mars missions, their two main objectives are the manned spaceflight program and the development of launch vehicles. In connection with Mars exploration, the design of the first Chinese Mars orbiter and Mars Rover has begun. Another important development is the Long March 5 rocket and they are also planning crewed and cargo spacecraft to map the Moon. ${ }^{16}$

A space station was constructed, and another one is to be built. China has trained astronauts. They can determine the mineral riches of the Moon a hundred meters down and in the coming period they will check and qualify the minerals, then the mining can begin in the designated sites or plants. China could be present in Earth's orbit in the long run with its own space station.

\footnotetext{
15 Ürvilág, 2019. Ürvilág.hu. [Online] Available at: http://www.urvilag.hu/a holdnal/20190819_a gateway_lakomodulja [Date of access: 0411 2020].

${ }^{16}$ Landy-Gyebnár, M., 2020. National Geographic. [Online] Available at: https://ng.24.hu/tudomany/2020/07/02/elobb-indulhat-a-kinai-marsjaro-mint-az-amerikai/ [Date of access: 05112020 ].
} 


\section{Space mining}

Space mining is yet a task hindered by great technological and financial barriers. Several companies have started research for minerals on asteroids, without any success.

Some question the legitimacy of the exploitation of space assets. According to the Outer Space Treaty national appropriation is prohibited in Space. The question is not whether space mining is permitted, but in what way and under what circumstances?

International lawyers think the legislation related to space mining should be similar to the well-established open sea and seabed legislation.

No state has sovereignty in the open sea, so there is no need to acquire international authorization to exploit resources. In contrast, excavation in the sea bed is strictly subject to authorization by the International Seabed Authority.

There have been efforts to elaborate a similar system, without any success. The Moon Treaty came into effect in 1984, and it provides for the setting up of an international system to supervise research and excavation on the Moon - however, it was only signed by 18 counties. This proves that countries present in space rather support voluntary guidelines, while countries not present in space are willing to take on international obligations. Such conflicting views are extremely harmful as for the renewability of the Moon Treaty, as well as a new international space agreement.

Based on all this, it can be rightly assumed that the only solution might be the model applied for the open sea. The United States and Luxembourg, both countries at the forefront of the aerospace industry, have already enshrined in law, that only companies registered in their territory can begin excavations in Space. ${ }^{17}$ The best solution would be cooperation, and adoption and adherence to common guidelines. The international authority should be obliged to inform its international associate institutions, when it authorizes an excavation is Space. To make possible human habitance, about the same infrastructural background is needed, that made Amazon successful.

\footnotetext{
${ }^{17}$ Kitekintő, 2019. Kitekintö.hu. [Online]

Available at: https://kitekinto.hu/2019/07/27/europan-kivul/otveneves-szabalyokkal-vagunk-neki-az-ur-

meghoditasanak/173806/

[Date of access: 0311 2020].
} 


\section{USA space industry venture}

The range of space entrepreneurs is widening; space technology development is shifting to civilians. The company of Elon Musk, SpaceX is likely to be the biggest logistic provider in the world. It carried 10 satellites aboard a single transporting rocket (Iridium-3 mission). The SpaceX Falcon 9 launch rocket delivered the 10 satellites in about 75 minutes, attaining a height of $628 \mathrm{~km}$, at a speed of $27.000 \mathrm{~km} / \mathrm{h}^{18}$

Jeff Bezos, founder of Amazon, owner of the Blue Origin rocket company, lectured on the probable future life in space of humanity. He thinks that in the future, people can live in Space, in artificial settlements of a capacity of 1 million people.

At the time of writing this article, Elon Musk American high-tech entrepreneur started his first full-fledged mission with his private space company, SpaceX, sending four astronauts to the International Space Station (ISS) in the Crew Dragon spacecraft, tested a semester ago. ${ }^{19}$

The complex Mars program could be fully launched from 2040 to the middle of the century. By then, life support on Mars will be designed in a reliable way; colonies will be formed, organized, local energy resources will be used, such as solar power or energy drawn from water, ice, rocks and minerals.

Safety and chemical protection procedures and industrialization will advance, while bases, energy hubs, space stations and technical assistance service stations will be fully built. Takeoff and landing of spacecrafts traveling beyond the Solar System will be possible.

There is a spacecraft experiment going on, where the flight operation is a single-stage procedure: between Moon-Earth and Earth-Moon. Blue Origin rocket performed a successful space jump.

\footnotetext{
18 Logisztika.blog.hu, 2017. Ürlogisztika: 10 müholdat pattintott fel 75 perc alatt Elon Musk csapata. [Online] Available at: https://logisztika.blog.hu/tags/informatika [Date of access: 0511 2020].

${ }^{19}$ Dr. Estók, S., 2020 (under publication). Az Ürhaderő és az Ürstratégia a többpólusú világban. (manuscript). Repüléstudományi közlemények.
} 
The space vehicle attained a height of $101.7 \mathrm{~km}$ after launch, then it successfully performed a powered vertical landing on a selected area. ${ }^{20}$ This experiment was remarkable and suggests that further success of Blue Origin will following the future. ${ }^{21}$

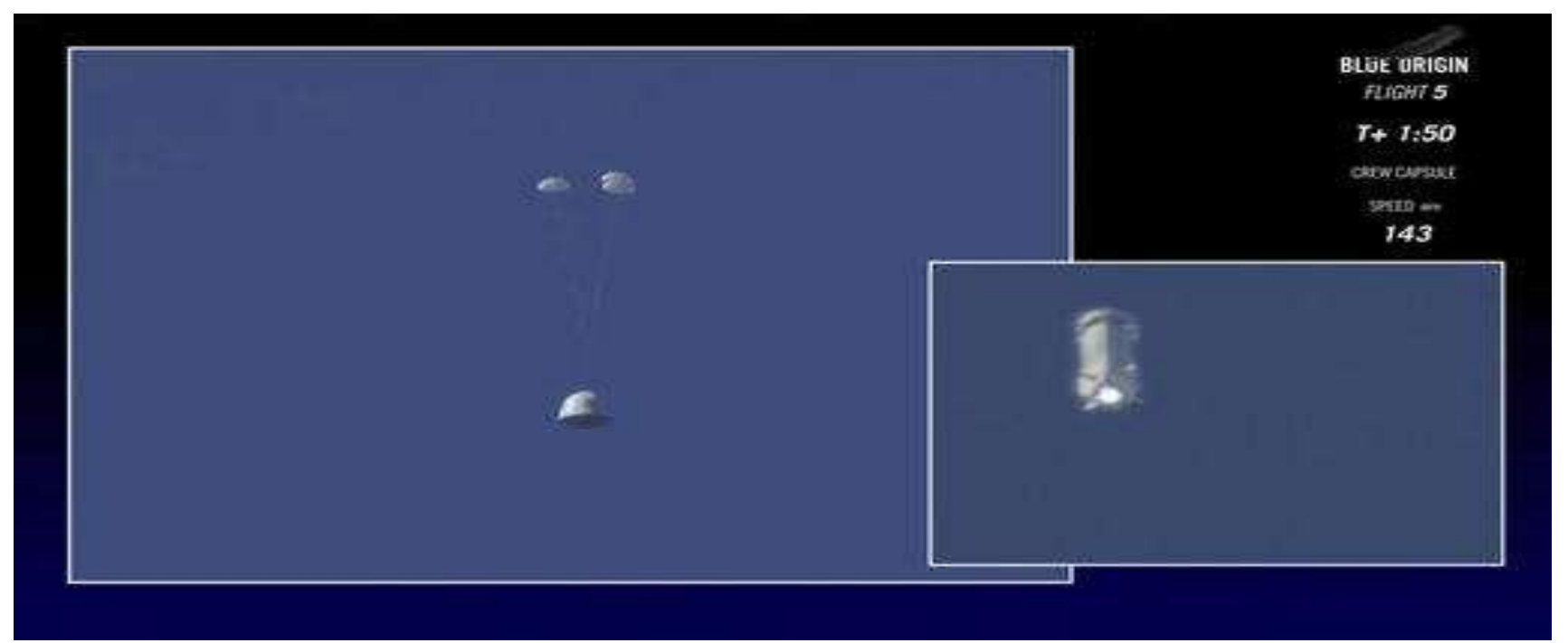

Blue Origin ${ }^{22}$

This was a double success for the Blue Origin rocket company and brought it one step closer to getting people in space. Blue Origin is the head of a consortium, of which the objective is to safely return humans from the Moon in 2024, within the framework of NASA's Human Landing System.

\footnotetext{
20 Ürvilág, 2019. Ürvilág.hu. [Online] Available at: http://www.urvilag.hu/a holdnal/20190819_a_gateway_lakomodulja [Date of access: 0411 2020].

${ }^{21}$ Dr. Estók, S., 2016. Holdhasznosítás müveleti logisztikai támogatásának biztonság és koc-kázat elemzése.. LOGISZTIKAI TRENDEK ÉS LEGJOBB GYAKORLATOK II, pp. pp. 56-58. , 3 p.

${ }^{22}$ Dr. Estók, S., 2020 (under publication). Az Ürhaderő és az Ürstratégia a többpólusú világban. (manuscript). Repüléstudományi közlemények
} 


\section{India, Japan, South Korea}

India has many launch vehicles; it observes the Earth from satellites during floods and monsoons. Besides, India would like to get involved in crewed space flights, but it is not expected to pick up the pace of competition.

Japan places great emphasis on military application; it observes North Korea.

South Korea has its own launch vehicle, carries out its own development.

\section{Introducing a culture of space logistics on the planets of the Solar System and beyond}

Space logistics is a reality and not a vision anymore, thinking about this, can we say it is an actuality?! This question cannot be answered right now, maybe after several lifetimes pass. However, we can state that logistics is there in Space, on several planets, Mars, Moon. During the past century countless space activities took place in outer space and there are many more foreseen tasks ahead in the near and further future. Several countries plan sending a man on the Moon in 2024, thus the tasks of space logistics become reality, based on ready-made plans. Every state headed to the Moon, to make some kind of use of it agree on the rationale of space logistics and acknowledge the presence of interdisciplinary logistic science in Space.

Thanks to scientific and technical progress, more and more countries acquire the capacity to get into space. In our days, the creation of a new type of living space and circumstances has begun in Space.

\section{Interdisciplinary space logistics}

In the near future, we might see the application of new scientific results as far as space logistics is concerned. A new type of logistic environment is being formed, where space logistics has an important strategic role, and it is becoming highlighted, with all its superstructures, organizations, tasks, technical equipment and the circumstances assured on a space base. Space logistics provides a number of variations for logistical support and although it still might seem a novelty, it will be an integral part of our lives in the decades to come.

The objective of logistic support, providing and services remains to ensure in cosmic environment similar conditions to human activity on Earth. This thought is still quite strange to 
us, we are still getting used to take account of space logistics as a fact. Logistic thinking, attitude and view are shifting to new characteristics, procedures and systems. The main issues - on Earth, as well as in Space - will be systems approach, process orientation and optimization. The principles of logistics: responsibility, supply, cooperation, principle of powers, sufficiency, flexibility, cost effectiveness, transparency will remain the same in Space. The logistic support chain will intensify in this expanded space by making use of military cooperation and synergies. This is a big challenge, that can be tackled by planets (Moon logistics, Mars logistics) or by tasks. ${ }^{23}$

Space logistics means the system and tasks during activity in Space are of logistical nature. Space logistics should be interpreted with a new vision and thinking, as a complex system, an elaborated project and a set of organized operations, involving a lot of unknown risks, because the culture of space logistics is yet unknown to people on Earth. Logistics is a strategic factor; in the $21^{\text {st }}$ century this is justified by the vision and program of the USA, China and Russia. The biggest challenge is to land a crewed spacecraft again on the Moon in 2024.

2020 is a turning point, when the big projects of several decades of the $21^{\text {st }}$ century end, and after 2020 the Moon base construction, exploitation, energy production, fusion power plant and mining power plant station construction may begin.

Parallel to the Mars program of the USA, the operation and reliable maintenance of the Moon project, the following may also start:

- implementation and maintaining the industrialization of Mars,

- development of food production opportunities

- laying the foundations of the processing industry

- then operation of distribution functions.

These plans also involve tasks related to space logistics, like the full logistic support of remote spaceflights. We can get beyond the Solar System, or to any planet of our own universe, but first we have to establish the logistic value and supply chains to Mars and the Moon. ${ }^{24}$

\footnotetext{
${ }^{23}$ Dr. Estók, S., 2008. Ürlogisztika: A logisztika kozmikus térben. TRANZIT: SZÁLLÍTMÁNYOZÁ-SI SZAKLAP (BALATONFÜRED) 9: szeptember, pp. pp. 58-59., 2 p.

${ }^{24}$ Dr. Estók, S., 2012. Ürlogisztika - Marsra szállás: Mars logisztika - vízió 2050. TRANZIT:

SZÁLLÍTMÁNYOZÁSI SZAKLAP (BALATONFÜRED) 13, pp. pp. 51-54. , 4 p.
} 
The main point in space logistics environment is life support logistics in the Solar System, which is an essential requirement. The protection of human life is a task that requires constant surveillance, as long as a human is on the planet. ${ }^{25}$

The logistics of subsistence and life support are a new direction and require a new culture of logistics. The protection should be customized, and rules should be strictly followed. It is in the interests of all people involved, to use and know mechanized systems. Medical surveillance can also be provided in cosmic conditions, while caves could be formed in mechanized and other ways to serve as a shelter against chemical radiation, unknown materials, raging storms, frost, and sandstorms.

The huge distances in Space make the areas to be examined (and their environment) quite dangerous. It is crucial to provide viable life and working conditions for humans and robots, especially in protection, resting, communal and service areas to be set up in lava caves.

The Moon has no atmosphere, to protect the personnel working there from unpredictably showering meteorites, solar wind and cosmic radiation, what is more, there is moon dust, which is able to infiltrate into the smallest opening on technical devices and human commodities. The temperature fluctuates a lot on the surface; the ground is hot during the day, and very cold at night. Shadows are black in the daytime, while the light is very bright and of high contrast, thus having a detrimental effect on the eyes and skin surface.

The poles of the Moon are four times colder than the poles of the Earth. For the human body, a night on the Moon is long and hard, and the temperature is very low, so technical devices, instruments, equipment, all have to be stored safely in a sheltered place, and constantly maintained in order to be suitable for use the next day. There are also unpredictable sources of danger, something unexpected may happen at any time, and cause that adverse circumstances await the personnel. ${ }^{26}$

A great threat menacing safety is the maintenance of human life support, materials and equipment, without which humans cannot exist on the Moon, so this needs to be available continuously, at any time of the day, according to human needs. ${ }^{27}$

One day on the Moon is equivalent to 14 days on Earth, this time is suitable for work.

\footnotetext{
${ }^{25}$ Dr. Estók, S., 2012. Ürlogisztika - Marsra szállás: Mars logisztika - vízió 2050. TRANZIT: SZÁLLÍTMÁNYOZÁSI SZAKLAP (BALATONFÜRED) 13, pp. pp. 51-54. , 4 p.

${ }^{26}$ Dr. Estók, S., 2015. Kozmikus ellátási láns a Föld és a Hold között. Hadtudományi Szemle, 8. kötet, pp. pp. 418-429, 12p.

${ }^{27}$ Dr. Estók, S., 2015. Kozmikus ellátási láns a Föld és a Hold között. Hadtudományi Szemle, 8. kötet, pp. pp. 418-429, 12p.
} 
Based on the production process of solar energy, green energy may be produced out of Helium (H3) by nuclear fusion without side effects under Earth conditions. ${ }^{28}$

It is quite possible, that today, at the end of the second decade of the $21^{\text {st }}$ century, we are at the doorstep of a new era: in 2-5 years we might witness another USA-Russia reunion, maybe also joined by China, which would be a meeting not at all determined by coincidence, but rather by the extraction of the riches and raw materials of the Moon. This new era could be called the "Moon mining era", a great epoch in the history of the world, the Moon, the Earth and the Solar System.

All these major powers have the Moon at the heart of their thinking. A good question might be, how they will divide it among themselves? Global players should sign a contract about the use of the Moon, it is only then, that they can tackle their elaborated strategy.

China has officially announced a quiet space strategy, and it started its space program in 1992. The Shenzhou 1 unmanned spacecraft was successfully launched and returned to Earth in the fall of 2003. But they were not satisfied with this: the head of the space program announced that they would like to land a man on the Moon and to explore it in the next decade to come. Maybe China is worth paying attention to! They are organizing and implementing successfully and persistently the space policy and space strategy of their country, as set out in the decisive White Paper. (ESTÓK)

The announcement of the $4^{\text {th }}$ stage took place on December 27 2016: they developed 17 versions of the 4 generations of rockets. By the end of 2016, 244 rocket launch experiments were made with 96\% success. The successful launch of Long March 5 in December 2019 the ambitious plans of China (mainly based on this rocket) became feasible. The key personalities of space activity announced, that besides the Moon and Mars research programs, objectives include a crewed space flight program and launcher development. ${ }^{29}$

\footnotetext{
${ }^{28}$ Szentgyörgyi, Z., 2015. A jövő nagy energiaígéretei. Metro Újság, 0402.

${ }^{29}$ Dr. Estók, S., 2013, Budapest. Az ürlogisztika dimenzióváltása - előttünk az univerzum: Az ürlogisztika kihívásai, jövőképe és jövőértékei a XXI. században (Ürtan Évkönyv 2012, Magyar Asztronautikai Társaság, (2013) ). pp. pp. 47-52..
} 


\section{Summary}

A new culture of logistics emerges in logistics science: the logistics of subsistence and life support that can be defined in general in relation to the Moon, as well as any other celestial body or planet. The most important things without which life is unthinkable:

- air rich in oxygen,

- special food,

- water,

- special clothing,

- warm accommodation,

- personal protection systems,

- special equipment,

- suitable shelter,

- storage space,

- working conditions,

- state of health,

- control systems,

- personal and central defense instruments,

- medical protection systems against freezing and colds, infections, diseases of unknown origin, chemical radiation and cosmic hazards,

- search and rescue systems,

- health disaster prevention systems,

- maintenance of services. (ESTÓK S. 2020)

In every mission the key factor will be man itself, exposed to unknown dangers and risks. The biggest challenge is to keep people alive and safe; without this, it all remains fantasy. ${ }^{30}$

${ }^{30}$ Dr. Estók, S., 2015. A XXI. század logisztikai kihívásai, trendjei és lehetőségei. LogisztikaiTrendek és Legjobb Gyakorlatok 1., pp. pp 35-38. 


\section{REFERENCES}

Ciolkovszkij, K. E., 1960. Távol a Földtöl. Budapest: Móra.

Csató, I., 1963. A kozmosz partján (Az ürkutatás története). Budapest: Kossuth Kiadó.

Csillagvizsgáló , b., 2020. Csillagvizsgáló Blog. [Online]

Available at:

https://csillagvizsgalo.blog.hu/2020/05/26/a_sas_leszallt_a_solyom_meg_fel_fog

[Date of access: 0211 2020].

Dr. Estók, S., 2012. Ürlogisztika - Marsra szállás: Mars logisztika - vízió 2050. 2. rész.

TRANZIT: SZÁLLÍTMÁNYOZÁSI SZAKLAP (BALATONFÜRED) 13, pp. pp. 48-50. , 3 p..

Dr. Estók, S., 2008. Ürlogisztika: A logisztika kozmikus térben. TRANZIT:

SZÁLLÍTMÁNYOZÁ-SI SZAKLAP (BALATONFÜRED) 9: szeptember, pp. pp. 58-59., 2 p.

Dr. Estók, S., 2012. Ürlogisztika - Marsra szállás: Mars logisztika - vízió 2050. TRANZIT:

SZÁLLÍTMÁNYOZÁSI SZAKLAP (BALATONFÜRED) 13, pp. pp. 51-54. , 4 p.

Dr. Estók, S., 2013, Budapest. Az ürlogisztika dimenzióváltása - előttünk az univerzum: Az ürlogisztika kihívásai, jövőképe és jövőértékei a XXI. században (Ürtan Évkönyv 2012, Magyar Asztronautikai Társaság, (2013) ). pp. pp. 47-52..

Dr. Estók, S., 2015. A XXI. század logisztikai kihívásai, trendjei és lehetőségei.

LogisztikaiTrendek és Legjobb Gyakorlatok 1., pp. pp 35-38..

Dr. Estók, S., 2015. Kozmikus ellátási láns a Föld és a Hold között. Hadtudományi Szemle, 8. kötet, pp. pp. 418-429, 12p.

Dr. Estók, S., 2016. Holdhasznosítás müveleti logisztikai támogatásának biztonság és kockázat elemzése.. LOGISZTIKAI TRENDEK ÉS LEGJOBB GYAKORLATOK II, pp. pp. 56-58. , $3 \mathrm{p}$.

Dr. Estók, S., 2020 (megjelenés alatt). Az Ürhaderő és az Ürstratégia a többpólusú világban. (kézirat). Repüléstudományi közlemények.

Hacker, B. C. \& Grimwood, J. M., 1977. On the Shoulders of Titans: A History of Project Gemini (PDF). NASA SP-420, Washington, D.C: MASA.

Kitekintő, 2019. Kitekintö.hu. [Online]

Available at: https://kitekinto.hu/2019/07/27/europan-kivul/otveneves-szabalyokkal-vagunkneki-az-ur-meghoditasanak/173806/

[Date of access: 0311 2020].

Landy-Gyebnár, M., 2020. National Geographic. [Online]

Available at: https://ng.24.hu/tudomany/2020/07/02/elobb-indulhat-a-kinai-marsjaro-mint-azamerikai/

[Date of access: 0511 2020].

Logisztika.blog.hu, 2017. Urlogisztika: 10 müholdat pattintott fel 75 perc alatt Elon Musk csapata. [Online]

Available at: https://logisztika.blog.hu/tags/informatika

[Date of access: 0511 2020].

Mailer, N., 2010. F. Moonfire - Az Apollo-11 hösies utazása - Az Apollo-11 hösies utazása. ISBN:9783836522298 szerk. hely nélk.:Taschen. 
Mizantroop, 2019. Mizantroop Blog. [Online]

Available at:

https://mizantroop.blog.hu/2019/07/21/holdra_szallas_ujra_vagy_marsra_szallas_eloszor

[Date of access: 0211 2020].

NASA, 2020. Lunar Rover Apollo 17. [Online]

Available at: http://images.jsc.nasa.gov/luceneweb/caption.jsp?photoId=AS17-146-22367

[Date of access: 2810 2020].

Portree, D. S. \& Trevino, R. C., 1997. Walking to Olympus: An EVA Chronology, NASA

History, Washington DC: NASA Headquarters.

Szentgyörgyi, Z., 2015. A jövő nagy energiaígéretei. Metro Újság, 0402.

Ürvilág, 2019. Ürvilág.hu. [Online]

Available at: http://www.urvilag.hu/a holdnal/20190819_a_gateway_lakomodulja

[Date of access: 0411 2020].

Wernher von Braun, 1966. History of rocketry \& space travel. hely nélk.:Crowell. 